\title{
The American Political Science Review
}

\author{
Vol. LXVII \\ June 1973 \\ No. 2
}

\section{CONTENTS}

415 The Structuring Principle: Political Socialization and Belief Systems

Donald D. Searing, Joel J. Schwartz and Alden E. Lind

433 Urbanization and Political Participation: The Case of Japan

Bradley M. Richardson

453 Aspects of Coalition Payoffs in European Parliamentary Democracies

Eric C. Browne and Mark N. Franklin

470 The Concept of Organizational Goal

Lawrence B. Mohr

482 Attitudes of the Arab Elite Toward Palestine and Israel

Michael W. Suleiman

490 Parties as Utility Maximizers

Donald A. Wittman

499 The Learning of Legislative Norms

Herbert B. Asher

514 The Strange Case of Relative Gratification and Potential for Political Violence: The V-Curve Hypothesis

Bernard N. Grofman and Edward N. Muller

540 The Relationship Between Seats and Votes in Two-Party Systems

Edward R. Tufte

555 Regression Analysis and Discriminant Analysis: An Application of R. A. Fisher's Theorem to Data in Political Science Fred Kort

560 A Research Ncte on Machine Politics as a Model for Change in a Philippine Province Louis P. Benson

567 Communications

579 Editorial Comment

582 Book Reviews and Essays

Review Symposium: Woodrow Wilson Reconsidered

Woodrow Wilson and the Study of Administration: A New Look at an Old Essay

Richard J. Stillman, II

Woodrow Wilson to 1902

Edward H. Buehrig

Office of publication: Curtis Reed Plaza, Menasha, Wisconsin.

Foreign Agent: P. S. King and Staples, Ltd., Great Smith Street, Westminster, London.

Second class postage paid at Washiogton, D.C., and at additional mailing offices.

Printed in the United States of America by George Banta Company, Inc., Menasha. Wisconsin.

Copyright, 1973, by The American Political Science Association 


\section{ARTICLES}

415 The Structuring Principle: Political Socialization and Belief Systems. This paper assesses the theoretical significance of data on childhood political learning. Two socialization models are involved. Each confers relevance on childhood learning by linking it with political outcomes. The first is an allocative politics model, which seeks a linkage with policy outputs. The other is a system persistence model, looking toward the stability and continued existence of political systems. Each model incorporates the following assumptions: (a) the primacy principle: childhood learning is relatively enduring throughout life; (b) the structuring principle: basic orientations acquired during childhood structure the later learning of specific issue beliefs.

It is this structuring principle which we examined and tested in the present paper. The data show no or little association between childhood orientations and the later learning of specific beliefs about the most important political issues of the day. Our evidence suggests a need to carefully reexamine the basic assumptions and directions of current political socialization research.

By Donald D. Searing, Associate Professor of Political Science, Joel J. Schwartz, Associate Professor of Political Science and ALden E. Lind, Assistant Professor of Political Science, University of North Carolina, Chapel Hill.

433 Urbanization and Political Participation: The Case of Japan. Research has shown that place of residence (urban-rural) has an ambiguous influence on political participation. Japan is one of several major nations in which rural people participate politically more than their urban counterparts. An analysis of urban-rural political attitudes in Japan shows some of the roots of the tendencies in participation. While urban residents are more psychologically involved in national politics, they also tend toward greater pessimism and have lower feelings of the vote being a duty than do their rural counterparts. In contrast, rural voters are highly dutiful in orientation, as well as being strongly involved in local politics and more concerned than urban residents about having their political needs represented. A Coleman effect parameter analysis of the urban-rural attitudes and political participation shows that the attitudes do in fact account for differences in political participation in local politics. But the attitudinal tendencies are less important for national political participation, and it is possible that the older social influence interpretation of Japanese urban-rural differences is most applicable to sectoral trends in this case.

By Bradley M. Richardson, Associate Professor of Political Science, Ohio State University.

453 Aspects of Coalition Payoffs in European Parliamentary Democracies. One important proposition about the distribution of coalition payoffs is found in W. A. Gamson's theory of coalition formation: "Any participant will expect others to demand from a coalition a share of the payoff proportional to the amount of resources which they contribute to a coalition." This proposition is tested in a universe of cabinet coalitions existing in thirteen European democracies during the postwar period. Here, payoffs to partners are indicated by the percentage share of cabinet ministries rezeived by parties for their percentage contribution of parliamentary seats/votes to the coalition.

The proportionality proposition is shown to hold strongly. Disproportionality, however, is observed to occur in distributions at the extremities of party size-large parties tend to be proportionately underpaid and small parties overpaid, the larger or smaller they become. This effect, how. ever, is most pronounced when the size of the coalition is small, and tends to reverse itself as the size of the coalition increases.

By ErIC C. Browne, Assistant Professor of Political Science, University of Wisconsin, Milwaukee, and Mark N. FrankLIN, Lecturer, University of Strathclyde.

470 The Concept of Organizational Goal. The organizational goal concept is important for significant types of organizational research but its utility has been downgraded in recent scholarship. This paper reviews critically key contributions to conceptualizing the organizational goal and synthesizes many of their elements into a more concrete and comprehensive conceptualization. The efforts of Etzioni, Seashore and Yuchtman, Simon, and Thompson to bypass the need for a goal concept in evaluative and other behavioral research are unconvincing in important respects. However, they are persuasive in underscoring the importance of viewing organizational goals as multiple and as empirically determined. Perrow, Gross, and others convincingly suggest a dual conceptualization, so that goals are dichotomized into those with external referents (transitive goals) and those with internal referents (reflexive goals). Deniston et al. contribute the desirability of subsetting the goals of organizations into "program goals" and of differentiating goals from both subgoals and activities. The existence and relative importance of organizational goals and an allied concept, "operative goals," may be operationally determined by current social science methods. The goal concept as presented here has implications for the evaluation of organizational effectiveness, for research on organizational behavior, for organization theory, and for views of the role of organizations in society.

By Lawrence B. Mohr, Associate Professor, Department of Political Science, and Research Associate, Institute of Public Policy Studies, University of Michigan. 
482 Attitudes of the Arab Elite Toward Palestine and Israel. Unlike most studies of the Arab-Israeli conflict, this one attempts not only to delineate the attitudes of Arab elite (professionals and university students) at home and abroad on the issue but also and primarily, to investigate the determinants of those attitudes. The sources include the relevant political literature, especially since the 1967 war; a set of depth interviews conducted among members of the elite in the Arab world; and a more structured sample survey conducted among Arab students and professionals in the U.S. Conclusions are based on the data from all three sources. The results show that religion, sectionalism, age, and level of education are important determinants of political attitudes and behavior among Arab elite. Neither locale (urban-rural residence) nor socioeconomic background, however, is found to be a significant factor.

By Michael W. Suleiman, Professor of Political Science, Kansas State University.

490 Parties as Utility Maximizers. The article introduces two models of political party decision making. Both models assume that the parties are solely interested in policy and that winning the election is just a means to that end. In one, the parties are competitive, while in the other the parties collude. The main result, in either case, is that the parties tend to be unresponsive to the interests of the voters.

The models are analyzed in an intransitive case (an election concerned only with income distribution) and a transitive one (an election where all political attitudes can be put on a left-right continuum), and under the assumptions of perfect and imperfect information.

With perfect information the intransitive case results in the parties ending up with all the income; while in the single peaked case neither party will have a position to the left (right) of the left (right) party's most preferred position whatever the attitudes of the voters.

Finally it is shown that it is rational for the parties to collude and present similar platforms.

By Donald A. Wittman, Assistant Professor of Economics, University of California at Santa Cruz.

499 The Learning of Legislative Norms. The paper focuses on the learning of legislative norms on the part of freshman members elected to the United States House of Representatives in November, 1968. Since a research interest in learning is a longitudinal concern, a two-page panel design was employed. the first set of interviews conducted in late January and February of 1969 and the second set the following May. As the concept of a norm involves the notion of shared expectations, a sample of the nonfreshman members of the 91 st Congress was also interviewed.

The main finding of the paper is that the amount of norm learning was surprisingly low; it appeared that freshmen largely knew the general House norms prior to entering Congress. And the extent of attitude change toward the norms once in office was minimal. Freshmen and nonfreshmen generally expressed similar attitudes toward the norms. Support for the norm of apprenticeship was found to be weak, suggesting the need to revise the traditional image of the freshman representative.

By Herbert B. Asher, Assistant Professor of Political Science, Ohio State University.

514 The Strange Case of Relative Gratification and Potential for Political Violence: The V-Curve Hypothesis. Perception of discrepancy between optimum level of achievement with respect to desired values and actual level of achievement is a concept that has figured importantly in explanations of collective violence and its subset, political violence (approval of and readiness to engage in behaviors which constitute progressively greater challenge to a political regime). Hypotheses about relationships between a number of static and dynamic achievement discrepancy constructs (labeled "relative gratification," and built from a variant of the Cantril Self-Anchoring scale) are tested. The achievement discrepancy constructs generally show only a weak degree of association with potential for political violence. However, measures of shift over time in discrepancy show an unexpected and intriguing relationship with potential for political violence: individuals who perceive negative change and individuals who perceive positive change show the highest potential for political violence, while individuals who perceive no change show the lowest potential for political violence; and this $V$-Curve relationship persists in the presence of various control variables. Moreover, absolute magnitude of shift in discrepancy from present to future shows a moderate degree of correlation with potential for political violence, and makes an independent contribution to a linear additive model. The data base is a sample of a population in which instances of political violence have been relatively frequent in the past.

By Bernard N. Grofman, Assistant Professor of Political Science, and Edward N. Muller, Associate Professor of Political Science, State University of New York at Stony Brook.

540 The Relationship Between Seats and Votes in Two-Party Systems. An enduring fact of life in democratic electoral systems is that the party winning the largest share of the votes almost always receives a still larger share of the seats. This paper tests three models describing the inflation of the legislative power of the victorious party and then develops explanations of the observed differences in the swing ratio and the partisan bias of an electoral system. The "cube law" is rejected as a description, since it assumes uniformity (which is not observed in the data) across electoral systems. Explanations for differences in swing ratio and bias are found in variations in turnout over districts, 
the extent of the "nationalization" of politics, and, most importantly, in who does the districting or reapportionment. The measures of swing ratio and partisan bias appear useful for the judicial evaluation of redistricting schemes and may contribute to the reduction of partisan and incumbent gerrymandering.

By Edward R. Tufte, Associate Professor of Politics and Public Affairs, Princeton University.

555 Regression Analysis and Discriminant Analysis: An Application of R. A. Fisher's Theorem to Data in Political Science. The conversion of multiple regression analysis to discriminant analysis is not only of theoretical interest, but-in view of the extensive use of these methods in political scienceit also has considerable value for applications. It is the purpose of this presentation to explain the underlying theoretical relationship and to demonstrate its application in the form of an example chosen from the judicial process. Specifically, the Supreme Court's acceptance or rejection of the fact that the defendant was not advised of his right to counsel in an involuntary confession case is considered as a function of the appearance, nonappearance, or denial of the fact in lower court records and appellate briefs. Since the acceptance or rejection of the fact by the Supreme Court is a dichotomous dependent variable, discriminant analysis is appropriate. It is shown in this study how discriminant analysis can be employed by initially using regression analysis, not only in the example presented for illustration, but in any situation in which a phenomenon with dichotomous manifestations may be examined as a function of specified variables.

By Fred KorT, Professor of Political Science, University of Connecticut.

560 A Research Note on Machine Politics as a Model for Change in a Philippine Province. The purpose of this research note was to determine whether Philippine politics could be characterized as fitting a "machine politics model" (James Scott, "Corruption, Machine Politics, and Political Development, APSR, 63 [December, 1969], 1142-1158). A province was selected which matched the criteria cited in Scott's model, and provincial political leaders and subleaders were asked to evaluate important considerations they used in deciding whom to support for public office.

Scott proposed that in electoral political systems, support moves from a dependence on deference to a dependence on particularistic rewards, and finally to dependence on ideology. Part of the study tested the three-phase model using factor analysis on ten variables generally thought to be crucial in Philippine politics. The factor analysis revealed six factors, three which matched Scott's three phases plus: the chance of winning, the use of threats, and party loyalty. Although Scott's three-phase model was rejected as inadequate, at the descriptive level the general attributes of machine politics (particularly as Philippine politics has moved from a reliance on deference and personal loyalty to a dependence on material reward) could be used to characterize Philippine politics.

By Louis P. Benson, Assistant Professor of Political Science, Kent State University.

567 COMMUNICATIONS

From James S. Coleman, Walter Dean Burnham, Charles H. Levine, Jeffrey L. Pressman, Bruce Gillespie, Robert G. Wesson, and Franklin W. Houn.

\section{BOOK REVIEWS AND ESSAYS}

582 Woodrow Wilson and the Study of Administration: A New Look at an Old Essay. Unquestionably, Woodrow Wilson's scholarly essay, "The Study of Administration," (1887) stands as an historic landmark in American administrative thought. As Leonard D. White once wrote, "Wilson's essay introduced this country to the idea of administration." Based upon the recent publication of the Woodrow Wilson papers by Princeton University Press, the present paper attempts to examine the origin and enduring contribution of Wilson's administrative thought. The central thesis of the paper is that Wilson's administrative theories grew out of the salient ideas of late nineteenth century America, particularly, Social Darwinism and the pressing demands for political reform. In many respects, however, Wilson's essay created more issues than it resolved since it failed to delineate clearly the substance and boundaries of the field of administration.

By Richard J. Stillman, II, Associate Professor of Public Administration, California State College, Bakersfield.

589 Woodrow Wilson to 1902. Arthur S. Link and associates, eds., The Papers of Woodrow Wilson. By Edward H. Buehrig, Professor of Political Science, Indiana University. 
592 Political Theory, History of Political Thought and Methodology

Paul Breines, ed., Critical Interruptions: New Left Perspectives on Herbert Marcuse. George Lichtheim, p. 592

William J. Chambliss and Robert B. Seidman, Law, Order and Power. Herbert L. Packer, p. 593

Serge Chermayeff and Alexander Tzonis, Shape of Community: Realization of Human Potential. Joseph Smucker, p. 594

R. W. Connell, The Child's Construction of Politics. M. Kent Jennings, p. 595

Louis Crompton, ed., assisted by Hilayne Cavanaugh, Bernard Shaw: The Road to Equality: Ten Unpublished Lectures and Essays, 1884-1918 With an Introduction by Louis Crompton. M. Susan Power, p. 596

Virginia Held, Kei Nielsen, Charles Parsons, eds., Philosophy and Political Action. Harry Girvetz, p. 597

Nigel Howard, Paradoxes of Rationality: Theory of Metagames and Political Behavior. John C. Harsanyi, p. 599

David S. Landes and Charles Tilly, eds., History as Social Science. W. B. Gallie, p. 600

Albert William Levi, Humanism and Politics. Allan Bloom, p. 602

Jack Lively, ed. and trans., The Works of Joseph de Maistre. Russell Kirk, p. 603

Alasdair MacIntyre, Herbert Marcuse, George Lichtheim, p. 592

David McLellan, ed. and trans., The Grundrisse, by Karl Marx. Shlomo Avineri, p. 604

K. Bruce Miller, Ideology and Moral Philosophy. Paul E. Sigmund, p. 605

Raymond Polin, L'Obligation Politique. Richard E. Flathman, p. 606

Herbert Read, Anarchy and Order; Essays in Politics. D. A. T. Stafford, p. 607

Paul Roazen, Freud: Political and Social Thought. Fred R. Dallmayr, p. 608

Robert S. Summers, ed., More Essays in Legal Philosophy. Hugo Adam Bedau, p. 610

Martin J. Wiener, Between Two Worlds: The Political Thought of Graham Wallas, Sugwon Kang, p. 612

613 American Government and Politics

Adam Carlyle Breckenridge, Congress Against the Court. Robert G. Seddig, p. 614

Richard M. Burkey, Racial Discrimination and Public Policy in the United States. Herbert Garfinkel, p. 614

Paul B. Downing, ed., Air Pollution and the Social Sciences: Formulating and Implementing Control Programs. Charles O. Jones, p. 616

Leon Friedman, The Wise Minority: An Argument for Draft Resistance and Civil Disobedience. William Gangi, p. 616

James M. Gerhardt, The Draft and Public Policy: Issues in Military Manpower Procurement 1945-1970. Clyde E. Jacobs, p. 617

Barbara Hinckley, The Seniority System in Congress. Stephen Horn, p. 618

Perry H. Howard, Political Tendencies in Louisiana. William C. Havard, p. 619

Charles O. Jackson, Food and Drug Legislation in the New Deal. James R. Woodworth, p. 621

Charles O. Jones, The Minority Party in Congress. David E. Price, p. 622

Frank Levy, Northern Schools and Civil Rights: The Racial Imbalance Act of Massachusetts. Edwin Andrus Gere, p. 623

Robert G. McCloskey, The Modern Supreme Court. Edited by Martin Shapiro. David Fellman, p. 625

Thomas K. McCraw, TVA and the Power Fight: 1933-39. Victor C. Hobday, p. 626

James E. McEvoy III, Radicals or Conservatives? The Contemporary American Right. Sheilah R. Koeppen, p. 626

Arnold Meltsner, The Politics of City Revenue. Martin A. Levin, p. 628

Barry A. Passett, Leadership Development for Public Service. Raymond Pomerleau, p. 630

James T. Patterson, The New Deal and the States: Federalism in Transition. William Anderson, p. 631

Henry S. Reuss, Revenue Sharing: Cruich or Catalyst? Lyle C. Fitch, p. 631

Neal Riemer, James Madison. Donald S. Lutz, p. 632

Alan H. Schechter, Contemporary Constitutional Issues. Robert A. Carp, p. 632

Marvin Schick, Learned Hand's Court. Irving Dilliard, p. 634

Gilbert Y. Steiner, The State of Welfare. Randall B. Ripley, p. 636

Gerald Stourzh, Alexander Hamilton and the Idea of Republican Government. Harvey Flaumenhaft, p. 637

William W. Turner, Power on the Right. Sheilah Koeppen, p. 626

639 Comparative Government and Politics

John Clarke Adams, The Quest for Democratic Law: The Role of Parliament in the Legislative Process. Norman Ward, p. 639

Iurii V. Arutiunian, Sotsial'naia struklura sel'skogo naseleniia SSSR. Rolf H. W. Theen, p. 640

Nnamdi Azikiwe, My Odyssey: An Autobiography. William Tordoff, p. 641

J. Bowyer Bell, The Myth of the Guerilla: Revolutionary Theory and Malpractice. Rex Mortimer, p. 642

John Patrick Bell, Crisis in Costa Rica: The 1948 Revolution. James L. Busey, p. 644

Robert Benewick, Political Violence and Public Order: A Study of British Fascism. Henry Steck, p. 646

André Bernard, ed,, Réflexions sur la Politique au Québec. 2nd Edition. Michael B. Stein, p. 660 
Noel Boaden, Urban Policy-Making: Influences on County Boroughs in England and Wales. G. W. Jones, p. 646

Otto Preston Chaney, Jr., Zhukov. Raymond L. Garthoff, p. 647

Eugenie Chang-Rodrigues, ed., The Lingering Crisis: A Case Study of the Dominican Republic. Abraham F. Lowenthal, p. 648

Chu-yuan Cheng, The Machine-building Industry in Communist China. Thomas G. Rawski, p. 649

Pran Chopra, ed., The Challenge of Bangla Desh. Anwar H. Syed, p. 650

Robert E. Cole, Japanese Blue Collar: The Changing Tradition. Marius B. Jansen, p. 652

Istvan Deak, Weimar Germany's Left-Wing Intellectuals: A Political History of the "Weltbulne" and lts Circle. Peter J. Fliess, p. 653

Reinhold August Dorwart, The Prussian Welfare State Before 1740. John R. Gillis, p. 654

David R. Evans, Teachers as Agents of National Development: A Case Study of Uganda. M. Crawford Young, p. 655

Francois Fejto, A History of the People's Democracies. Paul Shoup, p. 656

Ruth First, Power in Africa. Immanuel Wallerstein, p. 657

Sheila Fitzpatrick, The Commissariat of Enlightenment: Soviet Organization of Education and the Arts Under Lunacharsky. Gail Lapidus, p. 658

Francine R. Frankel, India's Green Revolution: Economic Gains and Political Costs. Stanley J. Heginbotham, p. 659

Maurice Giroux, La Pyramide de Babel. Michael B. Stein, p. 660

Roger F. Hackett, Yamagata Aritomo in the Rise of Modern Japan, 1838-1922. Sidney DeVere Brown, p. 662

James Harding, The Astonishing Adventure of General Boulanger. Cameron Nish, p. 664

Jan Hinderink and Mubeccel B. Kiray, Social Stratification as an Obstacle to Development: A Study of Four Turkish Villages. Noralou P. Roos and Leslie L. Roos, Jr., p. 665

Howard Palfrey Jones, Indonesia: The Possible Dream. Stephen Sloan, p. 666

Harold L. Kahn, Monarchy in the Emperor's Eyes: Image and Reality in the Chien-lung Reign. E. G. Pulleyblank, p. 667

Andrew D. Kalmykow, Memoirs of a Russian Diplomat: Outposts of the Empire, 1897-1917. Edited by Alexandra Kalmykow. Arthur E. Adams, p. 669

K. S. Karol, Guerrillas in Power: The Course of the Cuban Revolution. Carmelo Mesa-Lago, p. 670

Paul P. Kennedy, The Middle Beat: A Correspondent's View of Mexico, Guatemala, and El Salvador. Edited by Stanley R. Ross. John W. Sloan, p. 672

B. M. Khaketla, Lesotho 1970: An African Coup Under the Microscope. Richard F. Weisfelder, p. 673

Iltija H. Khan, Government in Rural India. Benjamin N. Schoenfeld, p. 669

Se-Jin Kim, The Politics of Military Revolution in Korea. John C. H. Oh, p. 674

Philip A. Kuhn, Rebellion and Its Enemies in Late Imperial China: Militarization and Social Structure, 1796-1864. Franz Michael, p. 675

Denis Laforte and André Bernard, La Legislation Electorale au Québec, 2nd edition. Michael B. Stein, p. 660

Jacques Lazure, La Jeunesse du Québec en Revolution. Michael B. Stein, p. 660

Arthur Liebman, Kennth N. Walker, and Myron Glazer, Latin American University Students: A Six Nation Study. Ronald M. Schneider, p. 676

Eliahu Likhovski, Israel's Parliament: The Law of the Knesset. Michael Kahan, p. 678

Peter C. Lloyd, Classes, Crises and Coups, Themes in the Sociology of Developing Countries. R. D. Scott, p. 679

Michael F. Lofchie, ed., The State of the Nations: Constraints on Development in Independent Africa Harvey Glickman, p. 680

Anthony Mascarenhas, The Rape of Bangla Desh Anwar H. Syed. p. 650

Thomas and Marjorie Melville, Guatemala: The Politics of Land Ownership. Roland H. Ebel. p. 682

Deborah D. Milenkovitch, Plan and Market in Yugoslav Economic Thought. Jozef Wilczynski, p. 683

Alan S. Milward, The New Order and the French Economy. Helen P. Liebel, p. 684

D. J. Murray, ed., Studies in Nigerian Administration. Alvin Magid, p. 685

Boniface I. Obichere, West African States and European Expansion: The Dahomey-Niger Hinterland, 18851898. Claude E. Welch, Jr., p. 686

Monte Palmer and Larry Stern, eds., Political Development in Changing Socieries. Frank Tachau, p. 687

Peter A. Poole, The Viemamese in Thailand: A Historical Perspective. Fred R. von der Mehden, p. 688

Aníbal Quijano, Nationalism and Capitalism in Peru: A Study in Neo-Imperalism. Trans. by Helen R. Lane. Jack W. Hopkins, p. 688

Erik Rasmussen and Erik Damgaard, eds., Scandinavian Political Studies. Vol. 6/71. Nils Andren, p. 689

Amal Ray, Tension Areas in India's Federal System. Norman D. Palmer, p. 690

Ronald Robinson, ed., Developing the Third World: The Experience of the Ninteen-Sixties. W. W. Rostow, p. 691

Abdul A. Said and Daniel M. Collier, Revolutionism. Rex Mortimer, p. 642

Sayre P. Schatz, Economics, Politics and Administration in Government Lending: The Regional Loans Boards of Nigeria. David B. Abernathy, p. 693 
Theoder Shanin, The Awkward Class. Political Sociology of Peasantry in Developing Society: Russia 19101925. Szymon Chodak, p. 694

Juan Angel Silen, We, The Puerto Rican People: A Story of Oppression and Resistance. William J. Brisk, p. 698

Alfred Stepan, The Military in Politics: Changing Patterns in Brazil. Robert A. Packenham, p. 694

Walter Stewart, Trudeau in Power. H. G. Thorburn, p. 696

Chester C. Tan, Chinese Political Thought in the Twentieth Century. Richard P. Suttmeier, p. 697

Pierre Elliott Trudeau, Approaches to Politics. H. G. Thorburn, p. 696

Melvin M. Tumin, with Arnold S. Feldman, Social Class and Social Change in Puerto Rico. William J. Brisk, p. 698

Eric R. Wolf, Peasant Wars of the Twentieth Century. Rex Mortimer, p. 642

Ehsan Yar-Shater, ed., Iran Faces the Seventies. James A. Bill, p. 700

Eberhard Zeller, The Flame of Freedom: The German Struggle Against Hitler. Trans. by R. P. Heller and D. R. Masters. George K. Romoser, p. 701

Valentin S. Zorin, ed., SShA: Problemy vnutrennei politiki (The USA: Domestic Policy Problems). Richard M. Mills, p. 702

704 International Politics, Law, and Organization

John Braeman, Robert H. Bremner, and David Brody, eds., Twentieth-Century American Foreign Policy. Stephen D. Kertesz, p. 704

Michael Brecher, The Foreign Policy System of Israel: Setting, Images, Process. J. C. Hurewitz, p. 705

Ian Brownlie, ed., Basic Documents on Human Rights. Louis B. Sohn, p. 707

Francis Deak, ed., American International Law Cases, Vol. I. Thomas M. Franck, p. 708

Margaret P. Doxey, Economic Sanctions and International Enforcement. Forest L. Grieves, p. 709

John W. Evans, The Kennedy Round in American Trade Policy: The Twilight of GAAT. Irving B. Kravis, p. 710

Bruno Fritsch, Die Vierte Welt: Modell einer neuen Wirklichkeit. Gerard Braunthal, p. 711

Theodore Geiger, Transatlantic Relations in the Prospect of an Enlarged European Community. Edward L Morse, p. 728

James Henry Giffen, The Legal and Practical Aspects of Trade with the Soviet Union. Revised edition. Robert Sharlet, p. 712

Theodore R. Giuttari, The American Law of Sovereign Immunity: An Analysis of Legal Interpretation. Guenter Weissberg, p. 713

Rainer Hellmann, The Challenge to U.S. Dominance of the International Corporation. Fouad Ajami, p. 714 Harold C. Hinton, The Bear at the Gate: Chinese Policymaking Under Soviet Pressure James L Nichols, p. 717

Charles Fred Iklé, Every War Must End. Paul Kecskemeti, p. 718

K. Jones and A. D. Smith, The Economic Impact of Commonwealth Immigration. E. J. B. Rose, p. 719

Luis Kutner, ed., The Human Right to Individual Freedom: A Symposium on World Habeas Corpus. Louis B Sohn, p 707

Daniel Lerner and Morton Gorden, Euatlantica: Changing Perspectives of the European Elites. Sidney Verba, p. 720

Richard H. Minear, Victors' Justice: The Tokyo War Crimes Trial. Theodore McNelly, p. 721

Michael Nicholson, Conflict Analysis. Raymond Tanter, p. 722

F. S. Northedge and M. J. Grieve, A Hundred Years of International Relations. Hedley Bull, p. 724

National Planning Association Advisory Committee, U.S. Foreign Economic Policy for the 1970s: A New Approach to New Realities. Robert E. Asher, p. 725

Lester B. Pearson, Chairman, Partners in Development: Report of the Commission on International Development. Raanan Weitz, p. 726

Robert E. Riggs, US/UN Foreign Policy and International Organization. H. Field Haviland, p. 727

Stuart A. Scheingold, The Law in Political Integration: The Evolution and Integrative Implications o, Regional Legal Processes in the European Community. Edward L. Morse, p. 728

Urs Schwarz, Confrontation and Intervention in the Modern World. I. William Zartman, p. 730

Steven L. Spiegel and Kenneth N. Waltz, eds., Conflict in World Politics. Fred A. Sondermann, p. 731

Maxwell D. Taylor, Swords and Plowshares: A Memoir. Bernard Brodie, p. 732

Arthur Campbell Turner, The Unique Partnership: Britain and the United States. F. S. Northedge, p. 733

Raymond Vernon, Sovereignty at Bay: The Multinational Spread of U.S. Enterprises. Fouad Ajami, p. 714

Harald von Riekhoff, German-Polish Relations, 1918-1933. George Brinkley, p. 734

Byron S. J. Weng, Peking's U.N. Policy: Continuity and Change. Allen S. Whiting, p. 735

Walter L. Williams, Jr., Intergovernmental Military Forces and World Public Order. Lincoln P. Bloomfield, p. 736

Mason Willrich, Global Politics of Nuclear Energy. Ralph Sanders, p. 737

S. S. Zarkovich, Le Programme des Nations Unies pour le Dèveloppement. Peter R. Baehr, p. 738 


\section{What if}

they gave an election and nobody came?

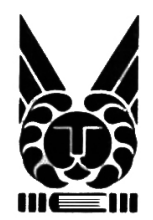

DILEMMAS OF SOCIAL REFORM: POVERTY AND COMMUNITY ACTION IN THE UNITED STATES (Second Edition)

\section{by Peter Marris and Martin Rein}

"The 2nd edition of Dilemmas of Social Reform is a valuable updating of a book that became a classic in the literature of urban politics and urban studies in just a few short years. It remains the best book on the efforts of various urban wars on poverty to improve the lives of the poor in the city. and its insightful analysis of the failure of these efforts has much to teach us about future such ef forts. I especially liked the new final chapter, for it is a thoughtfu and constructive analysis of the dilemmas, not just of social reform, but of democratic politics." - Herbert Ganz, Columbia University. Center for Policy Research.

\section{POLITICAL ALIENATION AND POLITICAL BEHAVIOR by David C. Schwartz}

"An outstanding job of synthesis, theory and construction and empirical validation. This book is likely to be judged one of the major contributions to political psychology of the decade."

\section{- Ted Robert Gurr, Northwestern University}

This book presents and confirms by extensive research a completely original three-variable psychological theory to explain the causes and consequences of political alienation and how psychological attitudes predict political behavior. The author shows why present theories of social status and economic difficulties do not adequately explain alienation and replaces them with theory based on observations of the following individual psychological phenomena: threat from value conflict, perceived personal inefficacy, and perceived systemic inefficacy. A process model for predicting political behavior is also stated and validated. This book will be of interest to many social scientists and will be especially important to anyone concerned with American politics and more generally with the relationships of economic, social, and psychological forces manifested in political behavior.

David C. Schwartz is presently Professor in the Political Science Department of Rutgers University and is the author of a number of articles published in major political science and behavioral science journals.

1973. 356 pp. $\$ 9.95$.

This second edition of a classic work on social reform brings the story of community action up to date from 1965 to 1971 . It is an account of the origins and development of community action from its beginnings in the Ford Foundation Gray Area Programs and the President's Committee on Juvenile Delinquency, through the rise and decline of the War on Poverty and the Model Cities Program. In a ruthlessly impartial examination of poverty programs two social scientists - one British, one American - explain why programs of such size and complexity have only a minimal chance of success. They describe the realities of reform and point up how the conservatism of bureaucracy, the rivalries among political and administrative jurisdictions, and the apathy of the poor have often hindered national and local efforts. On the other hand, they show how these obstacles can be overcome by an imaginative combination of leadership, democratic participation and scientific analysis.
Distinguished by an analysis of the major critics of community action. the book provides a balanced perspective of the movement against its many detractors. It is valuable for anyone engaged in community action, whether as organizer, consultant, official or politician.

Peter Marris is a member of the Institute of Community Studies in London. He has been a visiting lecturer in the Department of City Planning of the University of California, Berkeley, and is now working on a general study of social change. Martin Rein is Professor in the Department of Urban Studies and Planning at MIT. He has worked as a social worker with street gangs, has supervised a number of research projects, and has written about poverty. social planning, and the social work profession.

1973. 320 pp. \$8.50, cloth.

Aldine Publishing Company 529 South Wabash Avenue Chicago, Illinois 60605 


\title{
The American Political Science Association
}

\author{
1527 New Hampshire Ave. N.W., Washington, D.C. 20036
}

President: ROBERT E. WARD, University of Michigan; President-Elect: AVERY LEISERson, Vanderbilt University; Vice Presidents: Charles V. Hamilton, Columbia University; RALPH K. HuITT, National Association of State Universities and Land Grant Colleges; Ruth C. Silva, Pennsylvania State University; Secretary: Samuel Barnes, University of Michigan; Treasurer: CHARLes O. JONES, University of Pittsburgh; Program Chairman: LUCIAN PYE, Massachusetts Institute of Technology; Executive Director: EvRon M. KirkPATRICK, 1527 New Hampshire Avenue, N.W., Washington, D.C. 20036; Managing Editor, APSR: Nelson W. PolsBy, University of California, Berkeley.

COUNCIL: (Above-named Officers ex officiis), 1972-1973: CHRISTIAN BaY, University of Alberta; Samuel Dubois Coox, Duke University; Valerie Earle, Georgetown University; Richard F. Fenno, University of Rochester; Robert O. Keohane, Swarthmore College; SAMUel Krislov, University of Minnesota; Gerhard LoEWENBERG, University of Iowa; KENNETH PREwITT, University of Chicago. 1973-1974: Paul Y. Hammond, Rand Corporation; Donald G. Herzberg, Rutgers University; MatThew Holden, JR., University of Wisconsin, Madison; ROBERT HORWITz, Kenyon College; H. Mark Roelofs, New York University; Roberta S. Sigel, State University of New York, Buffalo; SIDNEY WISE, Franklin and Marshall College.

FORMER PRESIdents: Frank J. Goodnow, Albert Shaw, Frederic N. Judson, JAMEs Bryce, A. LAWRENCE Lowell, WOOdrow Wilson, Simeon E. BALDWIN, Albert Bushnell Hart, W. W. Willoughby, John Bassett Moore, Ernst Freund, Jesse Macy, Munroe Smith, henry Jones ford, Paul S. Reinsch, Leo S. Rowe, William A. Dunning, Harry A. Garfield, James W. Gardner, Charles E. Merriam, Charles A. Beard, William B. Munro, Jesse S. Reeves, John A. Fairlie, Benjamin F. Shambaugh, Edward S. Corwin, William F. Willoughby, Isidor Loeb, Walter J. Shepard, Francis W. Coker, arthur N. Holcombe, Thomas Reed Powell, Clarence A. Dykstra, Charles Grove Haines, Robert C. Brooks, Frederick A. Ogg, William anderson, Robert E. Cushman, Leonard D. White, John M. Gaus, Walter F. Dodd, Arthur W. Macmahon, Henry R. Spencer, Quincy Wright, James K. Pollock, Peter H. Odegard, Luther H. Gulick, Pendleton Herring, Ralph J. Bunche, Charles McKinley, Harold D. Lasswell, E. E. SchattSchneider, V. O. Key, Jr., R. Taylor Cole, Carl B. Swisher, EMmette S. Redford, Charles S. Hyneman, Carl J. Friedrich, C. Herman Pritchett, David B. Truman, Gabriel A. Almond, Robert A. Dahl, Merle fainsod, David Easton, Karl W. Deutsch, Robert E. Lane, Heinz Eulau.

\section{The American Political Science Review}

Department of Political Science, University of California, Berkeley 94720

EDTTORIAL BOARD: Nelson W. POLSBy, Managing Editor, University of California Berkeley; Philip Siegelman, Book Review Editor, California State University, San Francisco; SHLOMO AVINERI, The Hebrew University of Jerusalem; BRIAN BARRY, Nuffield Col lege, Oxford University; RICHARD A. BRODY, Stanford University; EDIrH T. CARPER, The Aerospace Corporation; SAMuel D. COOK, Duke University; S. Rufus Davis, Monash University; RoBert C. FRIED, University of California, Los Angeles; ARTHUR S. GOLDBERG, University of Rochester; MORTON H. HALPERIN, The Brookings Institution; Nannerl O. Keohane, Swarthmore College; Peter Laslett, Trinity College, Cambridge University; DALE Rogers MARShall, University of California, Davis, Russell D. MurPhy, Wesleyan University; JoAn M. Nelson, The Urban Institule; H. Douglas Price, Harvard University; Robert D. Putnam, University of Michigan. Douglas W. RaE, Yale University; Austin RanNey, University of Wisconsin, Madi. son; Grovanni Sartori, University of Florence; Michael J. SHaPIRo, University of Hawaii; Stephen V. Stephens, The Johns Hopkins University; George E. Von der MuHLl, University of California, Santa Cruz; RICHARD A. WATSON, University of Missouri. MANUSCRIPT EDITOR: Ellen Y. SIEgelMan. EDITORIAL ASSIS. TANTS: Barbara EPSTEIN, Barbara Kelly. EDITORIAL INTERNS: DOROTHY Clayton, Gerald Clayton, Peter Cowhey, Craig Garrett, Jeffrey Hart, Yvonne Jones, Beverly Kearns, Sam Kernell, David Laitin, Steven Lieberman, William M. Lunch, Ian Lustick, Jesse McCorry, Dan Metlay, Matthew Pinkus, Alex Radian, Brinton Rowdybush, Bryon Shafer, Robert StumpF, Stephen VaN Evera, Arthur Trueger, Harry Williams. 


\section{About the American Political Science Review}

The American Political Science Review, published quarterly during the months of March, June, September, and December, is supplied to all APSA members. Membership dues are charged according to the following schedule:

$\begin{array}{lr}\text { Membership Category } & \text { Dues } \\ \text { Regular } & \\ \text { Annual income } & \$ 20 \\ \text { Under } \$ 12,000 & \$ 25 \\ \$ 12,000-\$ 15,000 & \$ 30 \\ \text { Over } \$ 15,000 & \$ 10 \\ \text { Student and Retired } & \$ 5 \\ \text { Family } & \$ 1000 \\ \text { Life } & \$ 35 \\ \text { Institutional (includes APSR and PS) } & \end{array}$

Student memberships are limited to five years per person. Foreign currency at the official exchange rate will be accepted for foreign subscriptions and foreign membership fees. The equivalent of S1 for additional postage should be added for foreign subscriptions.

Current issues are priced at $\$ 7.50$ per copy; for back issues prior to 1968 address Johnson Reprint Corp., 111 Sth Ave., New York, N.Y. 10003; for issues 1968 and later eend request directly to the American Political Science Association.

Applications for membership, orders for the Review, and remittances should be addressed to the Executive Director, The American Political Science Association, 1527 New Hampshire Ave., N.W., Washington, D.C. 20036. Notices of changes of address should be received in the Washington office by the 25 th day of the months before publication.

\section{INSTRUCTIONS TO CONTRIBUTORS}

Address correspondence about contributions to the Review to Nelson W. Polsby, Department of Political Science, University of California, Berkeley, Berkeley, California 94720 . Each manuscript should be accompanied by an abstract of up to 150 words briefly describing the article's contents. All manuscripts and abstracts should be submitted IN DUPLICATE. They should be doublespaced and may be in typed, mimeographed, hectographed, or other legible form. Footnotes should appear at the end of the manuscript, not at the bottom of the page, and should also be doubled-spaced. Manuscripts that do not follow this format will be returned to the authors for retyping.

Since manuscripts are sent out anonymously for editorial evaluation, the author's name and affiliations should appear only on a separate covering page. All footnotes identifying the author should also appear on a separate page.

Address books intended for review to Philip Siegelman, American Political Sclence Review, 210 Barrows Hall, University of California, Berkeley, Berkeley, California 94720. Information, including News and Notes, for the Association's newsletter, PS, should be sent to 1527 New Hampshire Avenue, N.W., Washington, D.C. 20036; advertising, reprint and circulation correspondence should be sent to the Executive Director at the Washington office. Advertising information and rates are available from Nancy Edgerton, Adv. Manager, APSA, 1527 New Hampshire Avenue. N.W., Washington, D.C. 20036.

Articles and notes appearing in the Review before the June, 1953 issues were indexed in The Reader's Guide to Periodical Literature. Current issues are indexed by The International Political Science Abstracts and the Social Sciences and Humanities Index. Microfilm of the Review, beginning with Volume 1, may be obtained from University Microfilms, 313 North First Street, Ann Arbor, Michigan 48106. A Cumulative Index of the Review, Volumes 1-62: 1906-1968, may also be obtained from University Microfilms. Articles appearing in the Review are listed regularly in ABC Pol Scl and Current Contents: Behavioral, Social \& Management Sciences. 